\title{
Synthesis of Novel $\alpha$-Amino Acids Bearing 1,2,4-triazinone and Steroidal Moieties as Enzymetic Affect (Cellobiase Activity) Part I
}

\author{
Dina Abed Bakhotmah
}

Correspondence: Department of Chemistry, Faculty of Science, King Abdul-Aziz University, Jeddah, Saudi Arabia. E-mail: dbakhotmah@kau.edu.sa

Received: January 24, 2015 Accepted: February 17, 2015 Online Published: February 26, 2015

doi:10.5539/ijc.v7n1p98 URL: http://dx.doi.org/10.5539/ijc.v7n1p98

\begin{abstract}
An imperative class of $\alpha$-amino acids bearing 1,2,4-triazinone and $N, \mathrm{C}$-disubstituted glycine (5a,b) and/or the related systems (6 and 7) have been synthesized by the condensation of 6-(2'-aminophenyl-4-phenyl-3-thion -1,2,4-triazin-5-one (1) with the appropriate steroids, Epiandrosteron (2a) and Dehydrosterone (2b), followed by the addition of hydrocyanic acid. Nucleophilic substitution of mercapto group of (5) by 4-fluoroaniline and sulfanilamide give the corresponding systems 6 and 7. Compounds 6,7, 5, and 4 showed a high enzymatic effect as cellobiase agents against some tested fungi .
\end{abstract}

Keywords: $\alpha$-Amino acid, Cellobiase, Triazinone, Steroid, Sulfanilamide

\section{Introduction}

The $\alpha$-amino acid is important in the metabolic process. The steroids are considered significant controls in various metabolism relatedprocesses, whilevarious steroids with heterocyclic systems show biocidal affects (Janganti, Penthala, Cragle, MacNicol \& Crooks, 2004; Guo, Qiu, Yin \& Tianjin, 1999).

The 6-(2'-aminophenyl)-3-thioxo-1,2,4-triazin-5-ones derivatives showed biological and medicinal activities (Zhang, Wang \& Liu, 2012), on tumors (Abdel-Rahman, 1992 \& 2001; Abdel-Rahman, Seada, Fawzy \& El-Baz, 1994; Abdel-Mpnem \& Abdel-Rahman, 2006) and HIV (Abdel-Rahman, 1991; Abdel-Rahman, Morsy, Hnafy \& Amene, 1999; El-Gendy, Morsy, Allimony, Abdel-Monem \& Abdel-Rahman, 2001 ). In addition, it can have an amylolytic effect (Abdel-Rahman \& Abdel-Malik, 1990) and effect antimicrobial agents (Ebraheem et al., 2008; Abdel-Rahman \& Ali, 2013). Further modification via a redistribution of electron density over the active centers generate new kinds of $\alpha$-mino acids substituted with 1,2,4-triazine and glycine derivatives in view of their enzymatic affects against Aspergillus nidlans and Apergillus niger fungi

\section{Result and Discussion}

\subsection{Chemistry}

The key compound 6-(2'aminophenyl)3-thioxo-1,2,4-triazin-5(2H)-one (1) was synthesis by heating the isatin sodium salt with 4-phenylthiosemicarbzide at reflux for 2 hour, Scheme 1.

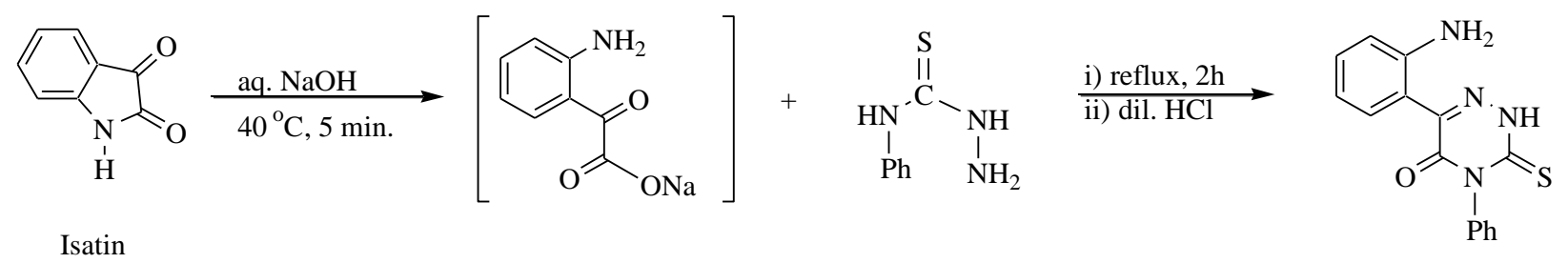

Scheme 1. Synthesis of triazinone 1

The ${ }^{13} \mathrm{CNMR}$ of compound 1 showed an interestingresonated signals at $\delta 185$ and 166 ppm attributed $\mathrm{C}=\mathrm{S}$ and $\mathrm{C}=\mathrm{O}$ respectively in addition to the aromatic carbons at $\delta 130-127 \mathrm{ppm}$.

The corresponding target of amino-1,2,4-triazineone 1 with steroids such as epiandrosteron and dehydrosterone $(\mathbf{2 a}, \mathbf{2 b})$ in THF yield the responding target amino-derivatives $\mathbf{3 a}$ and $\mathbf{3 b}$, respectively (Scheme 2).

The reactivity of exo and endo $\mathrm{C}=\mathrm{N}$ groups in the 1,2,4-triazines was studied (Üngören, Dilekoğlu \& Koca, 
2013; Abdel-Raman, 1992). Thus, the addition of $\mathrm{HCN}$ to the highly reactive exo $\mathrm{C}=\mathrm{N}$ of compound 3 gives [3'-thioxo-4'-phenyl-5'-ox-1,2,4-triazin-6'-phenylaimin-2'-yl]steroids (4a and $\mathbf{4 b})$, Scheme 2.

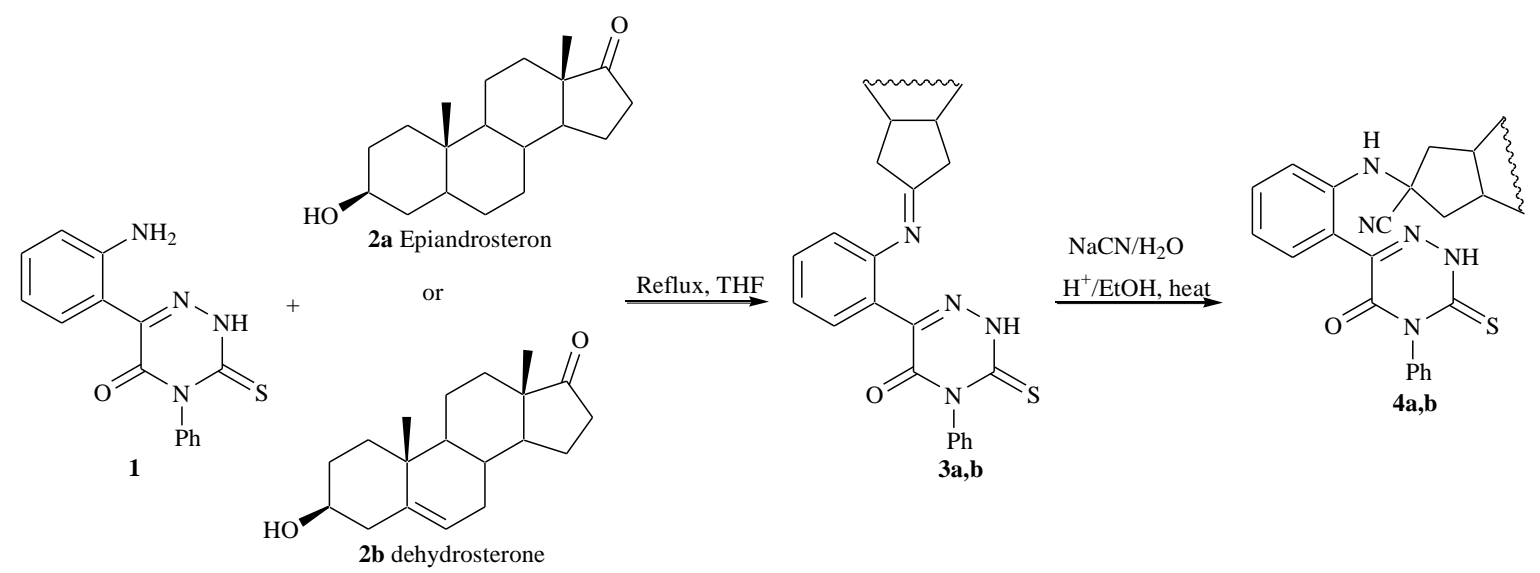

Scheme 2. Synthesis of amino-derivatives $3 \mathrm{a}$ and $3 \mathrm{~b}$

The acidic hydrolysis of compounds 4 yields the target $N$-substituted-C-substituted glycines $\alpha$-(4'-phenyl-3'-thioxo-5'-ox-2'H-1', 2', 4'-triazin-6-phenyl-2yl- $\alpha$-(steroid-17-yl)glycines (5a and 5b), Scheme 3 .

Selective installation of fluorine atom into a therapeutic or diagnostic molecule can enhance a number of pharmacokinetic and physicochemical properties (Delpon, 2008), such as improved metabolic stability and enhanced membrane permeation (Shah \& Westwell, 2007; Hagmann, 2008). An increased binding affinity of fluorinated drug candidates to target protein has also been reported (Filler \& Saha, 2009).

The isosteric isomer of azacytosine and 6-azauracil, 3-amino-1,2,4-triazin-5-ones is an interesting biological molecules due to its resistance to diaminese (Abdel-Rahman \& Fawzy, 1992; Makki, Bakhotmah \& Abdel-Rahman, 2012). In addition to previous work in cellobiase activates (Makki, Bakhotmah \& Abdel-Rahman, 2012; Abdel-Rahman, 1999, 2001; Mohammed, Makki, Abdel-Rahman \& Khan, 2014), a simple nucleophilic displacement of the SH group of compounds 5 using 4-fluoroaniline and/or sulfanilamide yield $\alpha$-[4'-phenyl-3"'-(4"-fluorophenyl)-5'-ox-1,2,4-triazin-6-phenyl-2'yl]- $\alpha$-[steroid-17'-yl]glycine $\quad(6)$ and /or $\alpha-[4$ '-phenyl-3' (4"sulfonamoyl phenylamino]glycine (7) respectively. Scheme 3.

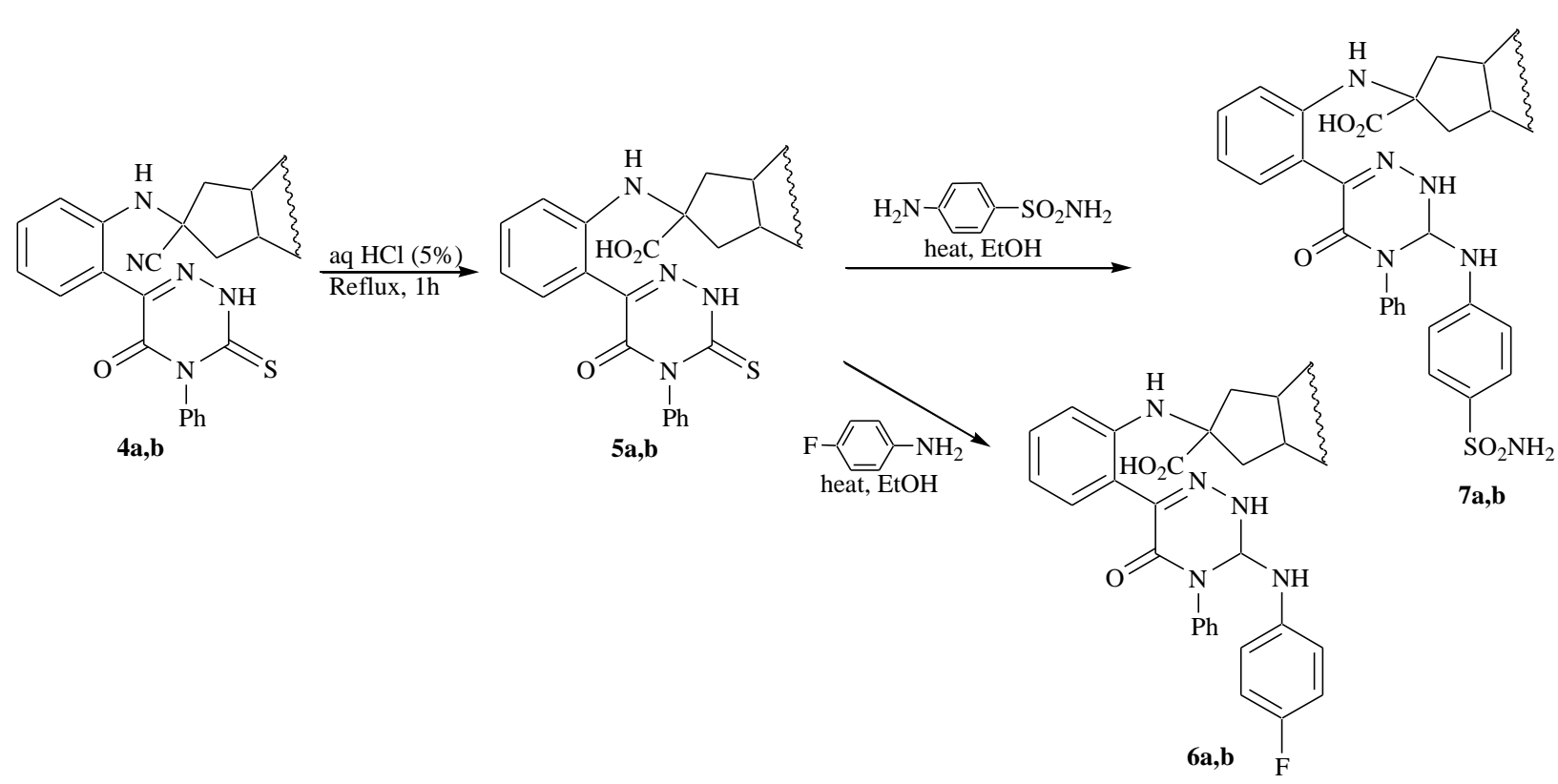

Scheme 3. Synthesis of glycine 6 and 7 


\subsection{Biologicalevaluation}

The effects of the synthesized $\alpha$-amino acid derivatives on the cellobase activity were studied using the Reese and Mandel procedure (Abdel-Aziz et al., 1996 ), ( $\mathrm{PH} \mathrm{5,} \mathrm{incubated} \mathrm{at} 40^{\circ} \mathrm{C}$ for 1 hour). The released reducing sugar was estimated calorimetrically at $540 \mathrm{~nm}$ (Ibrahim et al., 1997; Abdel-Rahman, Morsy, Allimon \& Abd El-Monem, 1999; Ibrahim et al., 2009), Table 1.

Table 1. effect on cellobiase activity produced by Aspergillus nidulans Aspergillns niger fungi

\begin{tabular}{lll}
\hline \multirow{2}{*}{ Compound } & \multicolumn{2}{l}{ Amount of glucose $(\mu \mathrm{g} / \mathrm{mL})^{*}$} \\
\cline { 2 - 3 } & Aspergillus nidulans & Aspergillns niger \\
\hline 1 & 0.66 & 0.68 \\
3 & 0.59 & 0.58 \\
$4 \mathrm{a}$ & 0.45 & 0.46 \\
$4 \mathrm{~b}$ & 0.41 & 0.43 \\
$5 \mathrm{a}$ & 0.72 & 0.75 \\
$5 \mathrm{~b}$ & 0.70 & 0.72 \\
$6 \mathrm{a}$ & 0.82 & 0.86 \\
$6 \mathrm{~b}$ & 0.80 & 0.81 \\
$7 \mathrm{a}$ & 0.76 & 0.78 \\
$7 \mathrm{~b}$ & 0.78 & 0.80 \\
\hline
\end{tabular}

* DMF $=0.73$ and $0.72(\mu \mathrm{g} / \mathrm{mL})$, blank= 0.97 and $0.80(\mu \mathrm{g} / \mathrm{mL})$ (without DMF)

Compounds $6 \mathbf{a}$ and $\mathbf{6 b}$ both showed a higher amount of activity over the compounds when compared against the other tested fungi, thus, the introducing of fluorine atoms and / or sulfa-drug moiety resulted in high order of activity in comparison with the corresponding $\alpha$-amino acids. Additionally, the presence of fluorine substituted $\alpha$-amino acids bearing 1,2,4-trizine and steroidal moieties led to increases the net-electronegativity, which improve the dielectric constant and enhances the hydrophobic properties. These properties, in all, increase their efficiency as enzymetic parameters.

In conclusion, the relationship between structural parameters, electronic parameter, and antifungalenzymatic activity ensures that the replacement of SH group of 1,2,4-triazine by substituted fluorine enhance the overall enzymetic effects.

\section{Experimental}

General Procedures

The melting points were determined using a Gallenkamp apparatus and were uncorrected, IR spectrum were recorded with FT-IR Bomem MB 104 using nujol mults and $\mathrm{NaCl}$ cells, NMR spectrums were obtained on Brukes Avance $400 \mathrm{MHz}$. chemical shift expressed in $\delta(\mathrm{ppm})$ using DMSO- $\mathrm{d}_{6}$, Mass spectrum were measured on GCMS Q1000-Ex at 70eV. Microbiological analyses were performed by the microanalytical center at Ain-Shams University, Egypt.

\subsection{6-(2'Aminophenyl)-4-phenyl-3-thioxo-1,2,4-triazin-5-one (1)}

A mixture of isatin $(0.001 \mathrm{~mol}$, in $5 \%$ aqueous $\mathrm{NaOH}, 50 \mathrm{ml})$, and 4-phenylthiosemicarbzide $(0.001 \mathrm{~mol})$ were refluxed for $2 \mathrm{~h}$.The cold reaction mixture was then added to cold $\mathrm{HCl}$. The formed solid is filtered, collected, and crystallized from ethanol to give $\mathbf{1}$ as orange crystals, yield $80 \%$, m.p. $220-222^{\circ} \mathrm{C}$.

IR $\left(\mathrm{cm}^{-1}\right), 3185,3120\left(\mathrm{~S}, \mathrm{NH}_{2}, \mathrm{NH}\right), 1660(\mathrm{C}=\mathrm{O}), 1190(\mathrm{C}=\mathrm{S}), 1590(\mathrm{C}=\mathrm{N}), 850(\operatorname{aryl~CH}) ;{ }^{1} \mathrm{HNMR}$ $\left(\right.$ DMSO-d $\left.\mathrm{d}_{6}\right) \delta(\mathrm{ppm}), 11.82,3.23\left(\mathrm{~s}, \mathrm{NH}\right.$ and $\left.\mathrm{NH}_{2}\right), 7.2-6.8\left(\mathrm{~m}, 9 \mathrm{H}\right.$, aromatic); ${ }^{13} \mathrm{CNMR}$ (DMSO-d $\left.\mathrm{d}_{6}\right) \delta(\mathrm{ppm}), 185$ $(\mathrm{C}=\mathrm{S}), 166(\mathrm{C}=\mathrm{O}), 130-127$ (aromatic); M/z, 297 (M+1, 12.11\%), 163 (100\%); CHNS analysis of the compound 1, $\mathrm{C}_{15} \mathrm{H}_{12} \mathrm{~N}_{4} \mathrm{SO}$ (296), calculated: C,60.8; H, 4.01; N, 18.69; S, 10.81. Found: C, 60.6; H, 4.0; N, 18.67; S, 10.79.

\subsection{7-[4-phenyl-3-thioxo-1,2,4-triazin-5-oxo-6-(phenyl-4-imino)] steroids ( 3 a and 3b)}

A mixture of $\mathbf{1}(0.001 \mathrm{~mol})$ and steroid epiandrosterone 2a and Dehydrosterone $\mathbf{2 b}(0.001 \mathrm{~mol})$ in $50 \mathrm{ml} \mathrm{THF}$ was heat to reflux for $2 \mathrm{~h}$. The cold solid was filtered and crystallized from ethanol to give 3a (yield 70\%; m.p. 212-213 ${ }^{\circ} \mathrm{C}$ ) and $\mathbf{3 b}$ (yield 68\%; m.p. 184-185 ${ }^{\circ} \mathrm{C}$ ).

IR (cm-1) 3a, $3382(\mathrm{OH}), 3010$ (aromatic CH), 2985 (aliphatic $\mathrm{CH}), 1670(\mathrm{C}=\mathrm{O}), 1616$ (exo $\mathrm{C}=\mathrm{N}), 1185(\mathrm{C}=\mathrm{S})$, 1480, 1440 (bending aliphatic CH); ${ }^{1} \mathrm{HNMR}\left(\mathrm{DMSO}_{6}\right) \delta(\mathrm{ppm}): 0.85\left(\mathrm{~s}, \mathrm{CH}_{3}, 18-\mathrm{H}\right), 1.85\left(\mathrm{~s}, \mathrm{CH}_{3}, 19-\mathrm{H}\right), 2.2$ and $2.5\left(\mathrm{~m}, \mathrm{CH}_{2}\right.$ steroide), $3.69\left(\mathrm{~s}, 17 \mathrm{a}-\mathrm{H}_{2}\right), 3.85\left(\mathrm{~s}, 4-\mathrm{H}_{2}\right), 5.55(\mathrm{~s}, \mathrm{OH}), 7.8-7.2(\mathrm{~m}, 9 \mathrm{H}$, aromatic $\mathrm{H}), 11.75(\mathrm{~s}$, $\mathrm{NH}, 1,2,4-$ triazine); M/z: 567 (M+1, 5.11\%), 163 (100\%, $\left.\mathrm{C}_{8} \mathrm{H}_{5} \mathrm{NSO}\right)$. 
CHNS Analysis for 3a: $\mathrm{C}_{36} \mathrm{H}_{40} \mathrm{~N}_{4} \mathrm{SO}_{2}$ (566), Calculated: C, 72.1; H, 7.1; N, 9.9; S, 5.7\%. Found: C, 72.4; H, 6.97; N, 9.7; S, 5.6\%. 3b: $\mathrm{C}_{34} \mathrm{H}_{38} \mathrm{~N}_{4} \mathrm{SO}_{2}$ (564), Calculated: C, 70.28; H, 6.62; N, 9.71; S, $5.54 \%$. Found: C, 70.30; H, $6.64 ; \mathrm{N}, 9.74 ; \mathrm{S}, 5.49 \%$.

\subsection{7-carbonitrile-17-[4-phenyl-3-thioxo-1,2,4-triazin-5-(2H) oxo-6-(2'-phenylamino) steroids (4a and 4b)}

A solution of $\mathrm{NaCN}\left(0.001 \mathrm{~mol}, 10 \mathrm{ml} \mathrm{H}_{2} \mathrm{O}\right)$ was added to compounds $3 \mathbf{a}$ or $\mathbf{3 b}(0.001 \mathrm{~mol})$, followed by the addition of $20 \mathrm{ml}$ of acetic acid/ ethanol mixture $(1: 1 \mathrm{v} / \mathrm{v})$. The reaction mixture was brought to reflux for $2 \mathrm{~h}$. The solid produced after cooling was collected by filtration and crystallized from ethanol to give 4a (yield 66\%, m.p. $219-220{ }^{\circ} \mathrm{C}$ ) or $\mathbf{4 b}$ (yield $68 \%$, m.p. $16-218^{\circ} \mathrm{C}$ ).

IR $\left(\mathrm{cm}^{-1}\right)$ 4a: $3400(\mathrm{OH}), 3180$ (exo NH), 3150 (endo NH), 3050 (ar CH), 2880 (aliphatic CH), $2215(\mathrm{CN}), 1666$ $(\mathrm{C}=\mathrm{O}), 1180(\mathrm{C}=\mathrm{S}) ;{ }^{1} \mathrm{HNMR}\left(\mathrm{DMSO}_{-} \mathrm{d}_{6}\right) \delta(\mathrm{ppm}): 11.45,8.85$ (s, exo and endo NH respectively), $0.88\left(\mathrm{~s}, \mathrm{CH}_{3}\right.$ for $18-\mathrm{H}), 1.86\left(\mathrm{~s}, \mathrm{CH}_{3}\right.$ for $19-\mathrm{H}$ ), 2.25 and 2.55 (m, $\mathrm{CH}_{2}$ steroid); ${ }^{13} \mathrm{CNMR}$ (DMSO-d $\left.{ }_{6}\right) \delta(\mathrm{ppm}): 12.23\left(\mathrm{C}_{18}\right.$, $\mathrm{Me}), 18.70\left(\mathrm{C}_{19}, \mathrm{Me}\right), 81.38(\mathrm{C}-\mathrm{OH}), 118.75(\mathrm{CN}), 168.35(\mathrm{C}=\mathrm{O}), 188.11(\mathrm{C}=\mathrm{S}) ; \mathrm{M} / \mathrm{z}: 597(\mathrm{M}+1,6.55 \%), 165$ (100\%, C8H7NSO);CHNS Analysis for $4 \mathbf{a}: \mathrm{C}_{37} \mathrm{H}_{41} \mathrm{~N}_{5} \mathrm{SO}_{2}$ (596), Calculated: C, 70.5; H, 6.9; N, 11.7; S, 5.4\%. Found: C, 70.1; H, 6.4; N, 11.6; S, 5.4\%.;4b: $\mathrm{C}_{37} \mathrm{H}_{39} \mathrm{~N}_{5} \mathrm{SO}_{2}$ (593), Calculated: C, 70.80; H, 6.58; N, 11.79; S, $5.41 \%$. Found: C, 70.78; H, 6.56; N, 11.78; S, 5.39\%.

\subsection{7-Carboxy-17-[4-phenyl-3-thioxo-1,2,4-triazin-5(2H)oxo-6-(2'-phenylamino)] steroids (5a and 5b)}

Compounds $4 \mathbf{a}$ and $\mathbf{4 b}(0.001 \mathrm{~mol})$ in $\mathrm{HCl}(5 \%, 20 \mathrm{ml})$ was reflux for $1 \mathrm{~h}$, the formed solid was filtered and crystallized from ethanol to give $\mathbf{5 a}$ (yield $65 \%$, m.p. $148-150{ }^{\circ} \mathrm{C}$ ) or $\mathbf{5 b}$ (yield $60 \%$, m.p. 222-224 ${ }^{\circ} \mathrm{C}$ ).

IR $\left(\mathrm{cm}^{-1}\right)$ : 3400-3350 (br, OH, NH), 3180-3130 (2NH), 3030 (ar CH), 2890 (aliphatic CH), 1685and 1665 (2 $\mathrm{C}=\mathrm{O}$ ), $1620(\mathrm{C}=\mathrm{N}), 1480$ and 1445 (bending $\mathrm{CH}_{2}$ steroid), $1180(\mathrm{C}=\mathrm{S}) ;$ ); ${ }^{1} \mathrm{HNMR}$ (DMSO-d $\left.\mathrm{d}_{6}\right) \delta(\mathrm{ppm})$ : 0.86 (s, $\mathrm{C} 18, \mathrm{Me}), 1.88$ (s, C19, Me), 2.25 and 2.55 (m, $\mathrm{CH}_{2}$ steroid), 3.70 (s, 1H), 7.75 and 7.18 (m, 9H, aromatic), 8.55 and $11.85(\mathrm{~s}, 2 \mathrm{NH}), 10.55(\mathrm{~s}, \mathrm{OH}) ;{ }^{13} \mathrm{CNMR}\left(\mathrm{DMSO}_{\mathrm{d}}\right) \delta(\mathrm{ppm}): 12.12\left(\mathrm{C}_{18}\right), 18.55\left(\mathrm{C}_{19}\right), 81.33\left(\mathrm{C}_{3}\right), 168.15$ $(\mathrm{C}=\mathrm{O}), 180.11(\mathrm{COOH}), 188.0(\mathrm{C}=\mathrm{S}) ; \mathrm{M} / \mathrm{z}: 627(\mathrm{M}+1,13.0 \%), 165(100 \%)$.

CHNS Analysis for 5a: $\mathrm{C}_{37} \mathrm{H}_{42} \mathrm{~N}_{4} \mathrm{SO}_{4}(614)$, Calculated: C, 69.0; H, 6.7; N, 8.9; S, 5.11\%. Found: C, 68.5; H, 6.6; N, 8.6; S, 4.9\%.;5b: $\mathrm{C}_{37} \mathrm{H}_{40} \mathrm{~N}_{4} \mathrm{SO}_{4}$ (612), Calculated: C, 69.20; H, 6.41; N, 8.97; S, 5.10\%. Found: $\mathrm{C}, 69.18 ; \mathrm{H}$, $6.39 ; \mathrm{N}, 8.95 ; \mathrm{S}, 4.09 \%$.

\subsection{7-Carboxy-17-[3-(4'fluorophenylamino)-4-phenl-5-oxo-1,2,4-triazine-6-(2'-phenylamino]steroids (6a and} 6b)

An equimolar of 4-fluoroaniline and $\mathbf{5 a}$ or $\mathbf{5 b}$ in $100 \mathrm{ml}$ ethanol was refluxed for $4 \mathrm{~h}$. The cold reaction mixture was then poured onto ice. The solid formed is collected by filtration and crystallized from ethanol to give 6a (yield $78 \%$, m.p. $185-187^{\circ} \mathrm{C}$ ) or $\mathbf{6 b}$ (yield $75 \%$, m.p. $130-132{ }^{\circ} \mathrm{C}$ ).

IR $\left(\mathrm{cm}^{-1}\right)$ : 3400-3380 (br, OH and NH), 3200-3150 (br, 2NH), 1680 and $1660(2 \mathrm{C}=\mathrm{O}), 1610(\mathrm{C}=\mathrm{N}), 1484,1444$ (bending $\mathrm{CH}_{2}$ ), 1250 (C-F), 905, 854 (aryl CH), 675 (C-F); ${ }^{1} \mathrm{HNMR}$ (DMSO-d $\left.\mathrm{d}_{6}\right) \delta(\mathrm{ppm})$ ): : 0.88, 1.88 (s, C18, Me andC19, Me), 2.20 and 2.50 (m, $\mathrm{CH}_{2}$ steroid), 3.85 (s, $\left.1 \mathrm{H}, \mathrm{C} 13\right), 6.41-6.60,6.82-7.23$ and $7.41-7.80(\mathrm{~m}, 13 \mathrm{H}$, aromatic), 8.55 and $11.85(\mathrm{~s}, 2 \mathrm{NH}), 10.55(\mathrm{~s}, \mathrm{OH}) ;{ }^{13} \mathrm{CNMR}\left(\mathrm{DMSO}-\mathrm{d}_{6}\right) \delta(\mathrm{ppm}): 12.6\left(\mathrm{C}_{18}-\mathrm{Me}\right), 17.0\left(\mathrm{C}-\mathrm{CH}_{2}\right)$, $18.7\left(\mathrm{C}_{19}-\mathrm{Me}\right), 44.0(\mathrm{C}-\mathrm{CH}), 81.66(\mathrm{C}-\mathrm{OH}), 142.11(\mathrm{C}-\mathrm{F}) 138.0(\mathrm{C}=\mathrm{N}), 162.0 \quad(\mathrm{COOH}), 168.0(\mathrm{C}=\mathrm{O})$;

CHNS Analysis for 6a: $\mathrm{C}_{41} \mathrm{H}_{46} \mathrm{~N}_{5} \mathrm{FO}_{4}(692)$, Calculated: C, 71.0; H, 6.6; N, 10.1; F, 2.7\%. Found: C, 71.0; H, 6.3; N, 9.7; F, 2.4\%.; 6b: $\mathrm{C}_{41} \mathrm{H}_{44} \mathrm{~N}_{5} \mathrm{FO}_{4}(690)$, Calculated: C, 71.03; H, 6.24; N, 10.10; F, 2.68\%. Found: C, 71.01; H, $6.21 ; \mathrm{N}, 9.08 ; \mathrm{F}, 2.65 \%$.

3.6 17-Carboxy-17-[3'-(4"'-aminosulfanomylphenylamino)-4-phenyl-5-oxo-1,2,4-triazine-6-(2"-phenylamino) steroids ( $7 a$ and $7 b$ )

A mixture of $\mathbf{5 a}$ or $\mathbf{5 b}(0.011 \mathrm{~mol})$ and sulfanilamide $(0.001 \mathrm{~mol})$ in absolute ethanol $(50 \mathrm{ml})$ was refluxed for 4h.The cold solid formed was filtered and crystallized from ethanol to give 7a (yield $66 \%$, m.p.140-142 ${ }^{\circ} \mathrm{C}$ ) or 7b (yield 68\%, m.p. 199-200 ${ }^{\circ} \mathrm{C}$ )

IR $\left(\mathrm{cm}^{-1}\right)$ : 3450-3340 (br, OH and NH), 3200-3180 (br, 2NH), 1686 and $1660(2 \mathrm{C}=\mathrm{O}), 1615(\mathrm{C}=\mathrm{N}), 1480,1440$ (bending $\mathrm{CH}_{2}$ ), $1350\left(\mathrm{SO}_{2}-\mathrm{NH}-\mathrm{R}\right), 910,850(\operatorname{aryl~CH}) ;{ }^{1} \mathrm{HNMR}\left(\mathrm{DMSO}-\mathrm{d}_{6}\right) \delta(\mathrm{ppm}):$ ): 0.81, $1.87(\mathrm{~s}, \mathrm{C} 18, \mathrm{Me}$ andC19, Me), 2.25 and 2.55 (each $\mathrm{m}, \mathrm{CH}_{2}$ steroid), 3.78 (s, 1H,C13), 6.41- 6.60, 6.85 -7.15 and 7.31-7.70(each $\mathrm{m}, 12 \mathrm{H}$, aromatic), 8.51 and 8.66 (each s, 2CH), $10.55(\mathrm{~s}, \mathrm{OH}), 11.80$ and $11.40(\mathrm{~s}, 2 \mathrm{NH})$; CHNS Analysis for 7a: $\mathrm{C}_{41} \mathrm{H}_{48} \mathrm{~N}_{6} \mathrm{SO}_{6}$ (753), Calculated: C, 65.3; H, 6.4; N, 11.2; S, 4.24\%. Found: C, 65.01; H, 6.1; N, 11.0; S, $4.1 \%$; 7b: $\mathrm{C}_{41} \mathrm{H}_{46} \mathrm{~N}_{6} \mathrm{SO}_{6}$ (751), Calculated: C, 65.51; H, 6.01; N, 11.02; S, 4.30\%. Found: C, 6.49; H, 5.89; N, $11.03 ; \mathrm{S}, 4.29 \%$. 


\section{Conclusion}

This study showed that the presence of fluorine atoms and /or sulfa-drug moiety, combined with $\alpha$-aminoacids, increases the cellobiase activity, while the carbonitrile derivatives decrease the tested bioactivity over the synthesized amino acid.

In addition, the incorporation of 5-ox-1,2,4-triazin-3-thione and a type of steroids to amino acid (glycine) initiatesthe potency of the novel synthesis systems, leading to the inhibition.It also accelerated its enzymatic affects.

\section{Acknowledgment}

I express my thanks to Prof. Reda Abdel-Rahman king Abdul-Aziz University for his support and guidance. Thanks are extending to Dr I. Ismail in the Microbiology center, Ain-Shams University, for her help in cellobiase evaluation.

\section{References}

Abdel-aziz, S. A., Allimony H. A. El-shaaer, H. M., Ali, U.F, Abdel-rahman, R. M. (1996). Fused Cyanopyrimidines: Part II Synthesis And Reactions Of Fused Cyanopyrimidine Derivatives As Affecting Enzymatic. Phosphorus, Sulfur, Silicon and the Related Elements, 113(1-4), 67-77.

Abdel-Monem, R. and Abdel-Rahman, R. (2006). Synthesis of 3-Heteroaryl-6,7-diphenyl-1,2,4-triazo-lo-[4,3-b] $[1,2,4]$ tria-zines and Their Biological Activities. International Journal of Chemistry, 16(1), 1-14.

Abdel-Rahman, R. (2001). Role of uncondensed 1,2,4-triazine compounds and related heterobicyclic systems as therapeutic agents. Pharmazie, 56(1), 18-22.

http://www.scopus.com/scopus/inward/record.url?eid=2-s2.0-0035044361\&partnerID=K84CvKBR\&rel=3. $0.0 \& \mathrm{md} 5=95 \mathrm{e} 14 \mathrm{caf} 3932 \mathrm{~d} 3 \mathrm{c} 69864602 \mathrm{a} 2 \mathrm{c} 501 \mathrm{~d} 46$.

Abdel-Rahman, R. (1991). Synthesis and anti human immune virus activity of some new fluorine containing substituted-3-thioxo-1,2,4-triazin-5-ones, Farmaco, 46(2), 379-389.

Abdel-Rahman, R. M. (1999). Synthesis and chemistry of fluorine containing bioactive 1,2,4-triazines - an overview: chemistry of uncondensed 1,2,4-triazines, part III. Pharmazie, 54(11), 791-803.

Abdel-Rahman, R. M., Morsy, J. M., Hanafy, F., \& Amene, H. A. (1999) Synthesis of heterobicyclic nitrogen systems bearing the 1,2,4-triazine moiety as anti-HIV and anticancer drugs: part I. Pharmazie, 54(5), 347-351.

Abdel-Rahman, R. (2001). Role of Uncondensed 1,2,4-Triazine Compounds and Related Heterobicyclic Systems as Therapeutic Agents. Pharmazie, 56, 18-30.

Abdel-Rahman, R. M., \& Abdel-Malik, N. S. (1990). Synthesis of Some New 3,6-Diheteroarryl-1,2,4-Triazine-5-one and Their Effect on Amylolytic Activity of Some Fungi. Pakistan Journal of Science and Industrial Research, 33, 142-147.

Abdel-Rahman, R. M., \& Ali, T. E. (2013). Synthesis and Biological Evaluation of Some New Polyfluorinated 4--Thiazolidinone and $\alpha$-Aminophosphonic Acid Derivatives. Monatshefte fur Chemie, 144, 1243-1252.

Abdel-Rahman, R. M., \& Fawzy, M. M. (1992). Addition Reactions of 3-Arylidene-5,6-diphenyl-1,2,4-triazenes, Asian J. Chem., 4(3), 621-628.

Abdel-Rahman, R. M. (1992). Synthesis of Some New Fluorine Bearing Tri-Substituted 3-Thioxo-1,2,4-Triazine-5- one as Potential Anti Cencer Agent. Farmaco, 47(3), 319-326.

Abdel-Rahman, R. M., Morsy, J. M., Allimony, H. A., Abd El-Monem, W. R. (1999). Synthesis of 3-(1,2,4-triazin-3-yl)-1,2,4-triazine derivatives and their effect on cellobiase activity. Bollettino Chimico Farmaceutico, 138(4), 176-185.

Abdel-Rahman, R. M., Seada, M., Fawzy, M., \& El-Baz, I. (1994). Synthesis of some new 1,6-dihydro-3-substituted 6-spiro-(9'-fluorene)-1,2,4-triazin-5-(4H)-ones as potential anti HIV and anticancer drugs. Pharmazie, 49(10), 729-733.

Abdel-Rahman, R. M., Seada, M., Fawzy, M., \& El-Baz, I. (1994). Synthesis of some new heterobicyclic compounds containingContaining spiro-1,2,4-triazine moiety as potential anti-HIV and anticancer agents. Pharmazie, 49(11), 811-814.

Bonnet-Delpon, D. (2008). Fluorine, an essential element for medicinal chemistry. Ann Pharm Fr., 66(1), 56-9. http://dx.doi.org/10.1016/j.pharma.2007.12.001. Epub 2008 Apr 2 French. PMID:18435988. 
Ebraheem, M., Abdel-Rahman, R., Abdel-Haleem, A., Ibrahim, S., \& Allimony, H. (2008). Synthesis and Antifungal Activity of Novel Polyheterocyclic Compound Containing Fused 1,2,4-Triazine Moiety. Arkivoc, 21, 202-213.

El-Gendy, Z., Morsy, J. M. Allimony, H. A. Abdel-Monem W. R., \& Abdel-Rahman, R. M. (2001). Synthesis of heterobicyclic nitrogen systems bearing the 1,2,4-triazine moiety as anti-HIV and anticancer drugs, part III. Pharmazie, 56(5), 376-383.

Filler, R., \& Saha, R. (2009). Fluorine in medicinal chemistry: a century of progress and a 60-year retrospective of selected highlights. Future Med Chem., 1(5), 777-91. http://dx.doi.org/10.4155/fmc.09.65.

Guo, L., Qiu, H., Yin, L., \& Tianjin, P. (1999). Phosphorus, Sulfur and Silicon, 147, 455-459.

Hagmann, W. (2008). The many roles for fluorine in medicinal chemistry. J Med Chem., 51(15), 4359-69. http://dx.doi.org/10.1021/jm800219f.

Hansen, M., Nielsen, J., \& Berg, K. (1989). J. Immunol Methods, 119, 203-210.

Ibrahim, M. A., Abdel-Rahman, R. M., Abdel-Halim, A. M., Ibrahim, S. S., \& Allimony, H. (2009). Synthesis, chemical reactivity and fungicidal activity of pyrido[1,2-b][1,2,4]triazine derivatives. Journal of the Brazilian Chemical Society, 20(7), 1275-1286.

Ibrahim, S. S., Abdel-Halim, A. M. Gabr, Y., El-Edfawy S., \& Abdel-Rahman, R. M. (1997). Synthesis and Biological Evaluation of Some New Fused Quinazoline Derivatives. J. Chem. Res. (S), 154-155.

Janganati, V., Penthala, N. R., Cragle, C. E., MacNicol, A. M., \& Crooks, P. A. (2004). Heterocyclic aminoparthenolide derivatives modulate $\mathrm{G} 2-\mathrm{M}$ cell cycle progression during Xenopus oocyte maturation. Bioorganic \& Medicinal Chemistry Letters, 24(8), 1963-1967.

Makki, M. S. T., Bakhotmah, D. A., \& Abdel-Rahman, R. M. (2012). Highly Efficient Synthesis of Novel FluorinFluorine e Bearing Quinoline-4-carboxylic Acid and the Related Compounds as Amylolytic Agents. International Journal of Organic Chemistry, 2(3A), 311-320. http://dx.doi.org/10.4236/ijoc.2012.223043.

Mohammed S. I. Makki, Reda M. Abdel-Rahman, \& Khalid A. Khan. (2014). Fluorine Substituted 1,2,4--Triazinones as Potential Anti-HIV-1 and CDK2 Inhibitors. Journal of Chemistry. http://dx.doi.org/10.1155/2014/430573

Mosmann, T. (1983). J. Immunol Methods, 65, 55-63.

Murray, P., Baron, E., Pfaller, M., Tenover, F., \& Yollen, R. (1992). In: G.L. Wood, J.A.Washington (Eds). Manual of Clinical Microbiology, Am. Soc. Microbial, Washington Dc.

Reese, M. (1963). Enzymatic hydrolysis of B-glucose, In advances in enzymatic hydrolysis of cellulose and related materials, edited by E.T. Reese, Pergmman Press. Oxford, 197.

Shah, P., \& Westwell, A. (2007). The role of fluorine in medicinal chemistry. J Enzyme Inhib Med Chem., 22(5), 527- 40. http://dx.doi.org/10.1080/14756360701425014

Üngören, S., Dilekoğlu, E., \& Koca, I. (2013). Synthesis of pyrazine-2,3-dicarbonitrile and 1,2,4-triazine-5 $(4 \mathrm{H})$-one derivatives from furan-2,3-diones[J]. CCL, 24(12), 1130-1133. http://html.rhhz.net/zghxkb/20131225.

Zhang, Y., Wang, X., \& Liu, W. (2012). Design, synthesis and biological evaluation of heterocyclic azoles derivatives containing pyrazine moiety as potential telomerase inhibitors. Bioorg. Med. Chem., 20, 63566365. http://dx.doi.org/10.1109/TCBB.2014.2326860

\section{Copyrights}

Copyright for this article is retained by the author(s), with first publication rights granted to the journal.

This is an open-access article distributed under the terms and conditions of the Creative Commons Attribution license (http://creativecommons.org/licenses/by/3.0/). 